\title{
Prevalence and Characteristics of Campylobacter Species Isolated from Gallbladder of Slaughtered Sheep in Van, (Eastern) Turkey
}

\author{
I. H. EKIN ${ }^{1}$, K. GÜRTÜRK ${ }^{1}$, A. ARSLAN ${ }^{2}$, B. BOYNUKARA ${ }^{1}$ \\ ${ }^{1}$ Department of Microbiology, Faculty of Veterinary Medicine, \\ ${ }^{2}$ Institute of Health Science, University of Yuzuncu Yil, Kampus-Van, Turkey \\ Received October 24, 2004 \\ Accepted November 10, 2005
}

\begin{abstract}
Ekin I.H., K. Gürtürk, A. Arslan, B. Boynukara: Prevalence and Characteristics of Campylobacter Species Isolated from Gallbladder of Slaughtered Sheep in Van, (Eastern) Turkey. Acta Vet. Brno 2006, 75: 145-149.

To determine the prevalence of campylobacter species in gallbladder of sheep in Van, (Eastern) Turkey, a total of 220 gallbladder samples from healthy slaughtered sheep were examined bacteriologically in October 2000 and 2002. Of the 110 samples examined each year, 27 (24.6\%) and $24(21.8 \%)$ campylobacter strains were isolated, respectively. Of the 27 campylobacter strains isolated in the year 2000, $14(51.9 \%)$ were identified as $C$. jejuni, $7(25.9 \%)$ C. fetus, $3(11.1 \%) C$. coli and $3(11.1 \%)$ C. lari. Similar results were obtained in the study performed in 2002, but C. lari could not be isolated. Growth and biochemical characteristics of all identified Campylobacter species with some exceptions were typical of each species. Six of 13 examined C. fetus strains grew well at both $25^{\circ} \mathrm{C}$ and $42^{\circ} \mathrm{C}$ in thioglycollate medium and on blood agar. C. jejuni strains differed from $C$. coli only by Na-hippurate hydrolysis test. Results of the present study revealed that $C$. jejuni is the most common campylobacter species isolated from gallbladders of sheep. The thermophilic campylobacters in significant proportions may cause contamination of carcass during slaughter and transmission of the food-borne pathogens to humans.
\end{abstract}

Prevalence, contamination, food-borne pathogens, Campylobacter species, bacteriology, identification, phenotype, strain, biochemistry

Campylobacters are important pathogens of humans and animals. C. fetus has been recognized as a cause of septic abortion, infectious infertility and diarrhoea in cattle and sheep (Varga et al. 1990; Gürtürk et al. 2000; Mannering et al. 2004). Thermophilic campylobacters such as $C$. jejuni, $C$. coli are also known as causal agents of abortions in sheep (Penner 1988; Gürtürk et al. 2002; Butzler 2004). C. jejuni and C. coli were found to be commensal in the rumens and small intestines of healthy calves and adult cattle. They cause acute gastroenteritis in human and enteritis in animals. C. jejuni is recognized as a causative agent of avian hepatitis of fowl (Butzler 2004; Tangvatcharin et al. 2005).

Nowadays, campylobacter species are a leading cause of food-borne diseases in the industrialized world. $C$. jejuni and $C$. coli are the most frequent species isolated from humans. The presence of campylobacter species in intestines and gallbladder of sheep may cause contamination of carcass during slaughtering and transmission of these foodborne pathogens to human beings by consumption of contaminated and low-heated sheep meat, meat products, liver or by direct contact with infected animals (Penner 1988; Butzler 2004; Blaser et al. 1983). Campylobacter species have been isolated from the intestines and gallbladders of apparently healthy sheep (Diker 1985; Wokatsch and Bockemühl 1988; Raji et al. 2000; Yazicioglu 2000). Previous studies (Diker 1985; Yazicioglu 2000; Ertas et al. 2003) indicated that the prevalence of Campylobacter spp. in the gallbladder of slaughtered sheep varied from $52.8 \%$ to $66 \%$ in some regions of Turkey.

Address for correspondence:

Dr. Ismail Hakki EKIN

Dept. of Microbiology, Faculty of Veterinary Medicine
University of Yuzuncu Yil

65080 Kampus-Van, Turkey
Phone: +90-432-2251128

Fax:: $+90-432-2251127$

GSM: +90-532-4957220

E-mail: ihekin@yyu.edu.tr

http://www.vfu.cz/acta-vet/actavet.htm 
The present study was performed to determine the prevalence of campylobacter species isolated from gallbladders of slaughtered sheep in Van, (Eastern)Turkey and to evaluate the biochemical characteristics for identifying campylobacter species.

\section{Materials and Methods}

Gallbladder samples

In October 2000 and 2002, 110 gallbladder samples for each year were collected from slaughtered sheep older than 1 year in Van,Turkey and were examined bacteriologically within $2 \mathrm{~h}$ of slaugther.

Isolation

A loop full of the gallbladder content was directly inoculated onto blood agar plates (Blood agar base No. 2, Oxoid-CM271, UK) containing 5\% defibrinated sheep blood and Skirrow selective supplements (Oxoid-SR069E, UK). The selective agar plates were cultured at $37^{\circ} \mathrm{C}$ for $48-72 \mathrm{~h}$ under aerobic and micro-aerobic atmosphere generated by using Campy-Gen (Oxoid-CN25, UK) in anaerobic jar (Oxoid-X1032, UK, without palladium catalyst) (Vandamme and Goossens 1992; On 1996).

Preliminary identification

Preliminary identification of campylobacter species was based on phenotypic characteristics; such as colony appearance, Gram staining, microscopic morphology, motility, catalase and oxidase reaction, nitrate reduction and fermentation of glucose (Holt et al. 1994; Nachamkin 1999).

Phenotypic identification

The following tests were performed for the identification of campylobacter species; $\mathrm{H}_{2} \mathrm{~S}$ production using lead acetate strips, hydrolysis of hippurate and indoxyl acetate, growth at $25^{\circ} \mathrm{C}$ and $42{ }^{\circ} \mathrm{C}$; growth in the presence of $1 \%$ glycine, $3.5 \% \mathrm{NaCI}$ and $0.04 \%$ Triphenyl Tetrazolium Chloride (TTC); sensitivity to $30 \mu \mathrm{g}$ nalidixic acid and cephalothine disks (Vandamme and Goossens 1992; Holt et al. 1994; On 1996). Growth and biochemical characteristics were examined in thioglycollate medium (Oxoid-CM391, UK). $\mathrm{H}_{2} \mathrm{~S}$ production was detected in brucella broth (Acumedia-7121, USA) with $0.02 \%$ cysteine by using lead acetate strips (Vandamme and Goossens 1992, Nachamkin 1999).

\section{Results}

A total of $27(24.6 \%)$ and $24(21.8 \%)$ campylobacter strains were isolated from gallbladders of slaughtered sheep in the years 2000 and 2002, respectively. All isolates were found to be Gram negative, motile, curved rods, catalase and oxidase positive, reducing nitrate, not utilizing glucose and growing microaerobically but not aerobically at $37^{\circ} \mathrm{C}$. Of the 27 strains isolated in the year 2000, 14 (51.9\%) were identified as $C$. jejuni, $7(25.9 \%)$ C. fetus, $3(11.1 \%)$ C. coli and $3(11.1 \%)$ C. lari. Similar results have obtained, but C. lari could not be isolated in the year 2002 (Table 1).

Table 1. Prevalence of Campylobacter species isolated from gallbladder of sheep at slaughterhouse in the years 2000 and 2002

\begin{tabular}{|l|c|c|c|}
\hline \multirow{2}{*}{ Campylobacter species } & \multicolumn{2}{|c|}{ Number (\%) of the strains isolated in the years } & \multirow{2}{*}{ Total } \\
\cline { 2 - 4 } & $2000^{*}$ & $2002^{*}$ & $13(5.9)$ \\
C. fetus & $7(6.4)$ & $6(5.5)$ & $28(12.7)$ \\
C. coli & $14(12.7)$ & $14(12.7)$ & $7(3.2)$ \\
C. lari & $3(2.7)$ & $4(3.6)$ & $3(1.4)$ \\
\hline Total & $3(2.7)$ & - & $51(23.2)$ \\
\hline
\end{tabular}

* A total of 110 samples were examined for each year

Further growth and biochemical characteristics of all examined campylobacter strains were typical of each species with some exceptions. The $C$. coli could be distinguished only by sodium-hippurate test from those of $C$. jejuni. Six $C$. fetus strains grew well at both $25^{\circ} \mathrm{C}$ and $42^{\circ} \mathrm{C}$ in thioglycollate medium and on blood agar. Except for $C$. fetus strains, 11 of 14 C. jejuni strains and all $C$. coli strains grew also in medium with presence of $0.04 \%$ TTC (Table 2 ). 
Table 2. Some characteristics of 51 Campylobacter strains isolated from gallbladder of slaughtered sheep

\begin{tabular}{|c|c|c|c|c|c|}
\hline Tests & & $\begin{array}{c}\text { C. fetus } \\
\text { (n: 13) } \\
\text { Pos./ Neg. }\end{array}$ & $\begin{array}{c}\text { C. jejuni } \\
\text { (n: 28) } \\
\text { Pos./ Neg. }\end{array}$ & $\begin{array}{c}\text { C. coli } \\
\text { (n: 7) } \\
\text { Pos./ Neg. }\end{array}$ & $\begin{array}{c}\text { C. lari } \\
\text { (n: 3) } \\
\text { Pos./ Neg. }\end{array}$ \\
\hline $\mathrm{H}_{2} \mathrm{~S}$ & Lead acetate strip & $13 / 0$ & $28 / 0$ & $7 / 0$ & $3 / 0$ \\
\hline \multirow[t]{2}{*}{ Growth at } & $25^{\circ} \mathrm{C}$ & $13 / 0$ & $0 / 28$ & $0 / 7$ & $0 / 3$ \\
\hline & $42{ }^{\circ} \mathrm{C}$ & $6 / 7$ & $28 / 0$ & $7 / 0$ & $3 / 0$ \\
\hline \multirow[t]{3}{*}{ Growth in presence of } & $1 \%$ Glycine & $13 / 0$ & $28 / 0$ & $7 / 0$ & $3 / 0$ \\
\hline & $3.5 \% \mathrm{NaCI}$ & $0 / 13$ & $0 / 28$ & $0 / 7$ & $0 / 3$ \\
\hline & $0.04 \%$ TTC* & $0 / 6$ & $11 / 3$ & $4 / 0$ & ND \\
\hline \multirow[t]{2}{*}{ Sensitive to } & Nalidixic acid & $0 / 13$ & $28 / 0$ & $7 / 0$ & $0 / 3$ \\
\hline & Cephalothine & $13 / 0$ & $0 / 28$ & $0 / 7$ & $0 / 3$ \\
\hline \multirow[t]{2}{*}{ Hydrolysis of } & Na-Hippurate & $0 / 13$ & $28 / 0$ & $0 / 7$ & $0 / 3$ \\
\hline & Indoxyl acetate & $0 / 13$ & $28 / 0$ & $7 / 0$ & $0 / 3$ \\
\hline
\end{tabular}

* The test was performed for the strains isolated in the year 2002 ND: Not Detected

\section{Discussion}

In the present study, the isolation rate of campylobacter strains from gallbladders of slaughtered sheep was determined as $24.6-21.8 \%$ in the years 2000 and 2002, respectively. These findings appeared to be lower than other reports (Diker 1985; Yazicioglu 2000; Ertas et al. 2003) in Turkey. In these reports, the prevalence of Campylobacter spp. in the gallbladders of slaughtered sheep was found to be $57.3 \%, 52.8 \%$ and $66 \%$, respectively. It has been reported that the isolation rate of campylobacter species from intestines or gallbladder of lambs and calves are higher than those of sheep and cattle (Diker 1985; Giacoboni et al. 1993). The lower isolation rate obtained in this study might be due to the fact that sheep examined in this study were older than one year of age.

Previous reports (Clarck and Mounbourgh 1979; Yazicioglu 2000) indicated that C. fetus is more prevalent than C. jejuni in the gallbladders of slaughtered sheep. In contrast, the results of this study revealed that the $C$. jejuni was found to be predominant campylobacter species in the gallbladder of slaughtered sheep. The distribution of campylobacter species were $12.7 \%$ C. jejuni, $6.4 \%$ C. fetus and $2.7 \%$ C. coli and C. lari in the year 2000. Similar results were also obtained in 2002. The isolation rate of $C$. jejuni, $C$. fetus and $C$. coli were $12.7 \%, 5.5 \%$ and $3.6 \%$, respectively, but $C$. lari could not be isolated in 2002. The differences in the occurrence and distribution of campylobacter species in gallbladder of sheep might be due to the differences in environmental and breeding conditions between areas or countries.

In agreement with other reports (Diker 1985; Yazicioglu 2000; Raji et al. 2000) C. coli was also detected in gallbladders of sheep examined in this study. C. coli are found to be common in humans and chickens but rare in sheep and cattle (Wokatsch and Bockemühl 1988; Bae et al. 2005). On the other hand, C. jejuni and C. coli could be recognized as separate species based on the hippurate hydrolysis reaction (Griffiths and Park 1990; Waino et al. 2003). The speciation was also confirmed using DNA-DNA hybridization techniques (Vandamme and Goossens 1992). Although the hippurate hydrolysis is a useful test for distinguishing $C$. coli and $C$. jejuni strains, there are some misidentifications with wild hippurate-negative $C$. jejuni strains (Griffiths and Park 1990; Waino et al. 2003). Totten et al. (1987) reported that the hippurate-negative campylobacter strains were identified as C. jejuni $(20 \%)$, C. coli $(78 \%)$ and $C$. lari $(2 \%)$ by DNA hybridization test. Ronner et al. (2004) indicated that the $C$. jejuni strains, $5 \%$ from human and $10 \%$ from chicken, found to be negative with Na-hippurate test after genotyping 
based on PCR/REA. In the present study, both thermophilic campylobacter strains differed only by hippurate test.

In addition, our study indicated that the tests for growth in presence of TTC and hydrolysis of indoxyl acetate appeared to be more characteristic of $C$. jejuni (except to three strains) and $C$. coli strains, but not for $C$. fetus and $C$. lari which were negative by both tests (On 1996; Holt et al. 1994; Nachamkin 1999).

However, six strains of C. fetus grew well at both $25^{\circ} \mathrm{C}$ and $42{ }^{\circ} \mathrm{C}$, and this property did not change after several culture passages. Because all other characteristics were typical, these thermophilic strains were identified as C. fetus (Penner 1988; Holt 1994). The thermophilic strains of $C$. fetus isolated from humans (Anstead et al. 2001; Woo et al. 2002) and from aborting sheep (Varga et al. 1990) have already been reported.

The $C$. lari strains identified in this study were resistant to both nalidixic acid and cephalothine, negative in hippurate test and grew well at $42{ }^{\circ} \mathrm{C}$ but not at $25^{\circ} \mathrm{C}$ as reported by VanDamme and Goossens (1992) and Raji et al. (2000). These strains were described as "NARTC" (nalidixic acid resistant thermophilic campylobacter) strains. C. lari is rarely isolated from the intestines of healthy sheep or cattle and did not appear to be associated with disease (Penner 1988; Butzler 2004; Diker 1985).

In conclusion, the prevalence of campylobacter species in gallbladder of slaughterhouse sheep was found to vary from $21.8 \%$ to $24.6 \%$ in Van, (Eastern) Turkey. C. jejuni are found to be the most common campylobacter species in gallbladder of sheep. Presented data showed also that the gallbladder of sheep containing thermophilic campylobacters in significant proportions may cause contamination of carcass during slaughter and transmission of the food-borne pathogens to humans. Even if the biochemical characteristics are suitable to confirm the preliminary identification of the campylobacter isolates on the species level, additional molecular biological techniques should be applied to reliable identification of the hippurate-negative campylobacter isolates.

\section{Rozšíření a charakteristika druhů baktérie Campylobacter izolovaných ze žlučníku jatečních ovcí v provincii Van ve východním Turecku}

Pro určení rozšîření druhů baktérie rodu Campylobacter ve žlučníku ovcí v provincii Van ve východním Turecku bylo bakteriologicky vyšetřeno celkem 220 vzorků žlučníku zdravých jatečních ovcí v říjnu roku 2000 a 2002 . Ze 110 vzorků vyšetřených v každém roce bylo izolováno 27 (24,6\%), resp. 24 (21, $8 \%$ ) druhů baktérie Campylobacter. Z 27 druhů izolovaných v roce 2000 bylo $14(51,9 \%)$ identifikováno jako C. jejuni, $7(25,9 \%)$ jako C. fetus, $3(11,1 \%)$ jako $C$. coli a $3(11,1 \%)$ jako $C$. lari. Podobných výsledků bylo dosaženo při výzkumu provedeném v roce 2002, avšak $C$. lari se izolovat nepodařilo. Typický pro všechny identifikované druhy baktérie Campylobacter byl, až na několik výjimek, růst a biochemická charakteristika. Šest ze 13 zkoumaných kmenů $C$. fetus dobře rostlo jak při $25^{\circ} \mathrm{C}$, tak při $42^{\circ} \mathrm{C}$ v thioglykolátovém médiu a na krevním agaru. Kmen $C$. jejuni se odlišoval od $C$. coli pouze při hydrolýze Na-hippurátu. Výsledky této studie ukázaly, že $C$. jejuni je nejběžnějším druhem baktérie Campylobacter izolovaným ze žlučníku ovcí. Termofilní baktérie rodu Campylobacter se mohou významně podílet na kontaminaci masa při porážce a přenosu patogenů potravinami na lidi.

\section{Acknowledgements}

We are thankful to the Presidency of Scientific Research Projects of University of Yuzuncu Yil for the support of this study.

\section{References}

ANSTEAD G, JORGENSEN J, CRAIG F, BLASER M, PATTERSON T 2001: Thermophilic multidrug-resistant Campylobacter fetus infection with hypersplenism and histiocytic phagocytosis in a patient with acquired immunodeficiency syndrome. Clin Infect Dis 32: 295-296 
BAE W, KAYA KN, HANCOCK DD, CALL, DR, PARK, YH, BESSER TE 2005: Prevalence and antimicrobial resistance of thermophilic Campylobacter spp. from cattle farms in Washington State. Appl Environ Microbiol 71: $169-174$

BLASER MJ, TAYLOR DN, FELDMAN RA 1983: Epidemiology of Campylobacter jejuni infections. Epidemiol Rev 5: 157-76

BUTZLER JP 2004: Campylobacter, from obscurity to celebrity. Clin Microbiol Infect 10: 868-876

CLARCK BL, MOUNBOURGH MJ 1979: The prevalence of Campylobacter fetus in the gallbladder of Sheep. Aust Vet J 55: 42-43

DIKER KS 1985: Studies on identification of campylobacter species isolated from sheep and cattle. Doga Turk Vet Hay Derg D1 9: 232-240

ERTAS HB, OZBEY G, KILIC A, MUZ A 2003: Isolation of Campylobacter jejuni and Campylobacter coli from the gall bladder samples of sheep and identification by polymerase chain reaction. J Vet Med B 50: 294-297

GIACOBONI IG, ITOH K, HIRAYAMA K, TAKAHASHI E, MITSUOKA T 1993: Comparison of fecal Campylobacter in calves and Cattle of different ages and Areas in Japan. J Vet Med Sci 55: 55-559

GRIFFITHS PL, PARK RVA 1990: Campylobacter associated with human diarrhoeal disease. A review. J Appl Bacteriol 69 : 281-301

GURTURK K, SOLMAZ H, EKIN IH, AKSAKAL A, GULHAN T 2000: Bacteriological and serological examinations of aborting sheep in Van region. J Faculty Vet Med University of Yuzuncu Yil 11: 19-22

GURTURK K, EKIN IH, AKSAKAL A, SOLMAZ H 2002: Detection of Campylobacter antibodies in sheep sera by a Dot-ELISA using acid extracts from C.fetus ssp.fetus and C.jejuni strains and comparison with a complement fixation test. J Vet Med B 49: 146-151

HOLT JG, KRIEG NR, SNEATH PHA, STALEY JT, WILLIAMS ST 1994: Bergey's Manual of Determinative Bacteriology. 9th Edition Williams \& Wilkins, Baltimore USA, pp. 41-64

MANNERING SA, WEST DM, FENWICK SG, MARCHANT RM, PERKINS NR, O'CONNELL K 2004: Pulsed-field gel electrophoresis typing of Campylobacter fetus subsp. fetus isolated from sheep abortions in New Zealand. N Z Vet J 52: 358-363

NACHAMKIN I 1999: Campylobacter and Arcobacter. In: MURRAY, PR, BARON EJ, PFALLER MJ, TENOVER FC, YOLKEN RH (Eds.) Manual of Clinical Microbiology. 7th ed., ASM Press, Washington DC $716-726$

ON, SLW 1996: Identification methods for Campylobacters, Helicobacter and related organisms. Clin Microbiol Rev 9: 947-953

PENNER JL 1988: The Genus Campylobacter: a Decade of Progress. Clin Microbiol Rev 1: 157-172

RAJI MA, ADEKEYE JO, KWAGA JKP, BALE JOO 2000: Bioserogrups of Campylobacter species isolated from sheep in Kaduna State, Nigeria. Small Rum Res 37: 215-221

RONNER AC, ENGVALL EO, ANDERSSON L, KAIJSER B 2004: Species identification by genotyping and determination of antibiotic resistance in Campylobacter jejuni and Campylobacter coli from humans and chickens in Sweden. Int J Food Microbiol 96: 173-179

TANGVATCHARIN P, CHANTHACHUM S, KOPAIBOON P, INTTASUNGKHA N, GRIFFITHS MW 2005: Comparison of methods for the isolation of thermotolerant Campylobacter from poultry. J Food Prot 68: 616-20

TOTTEN PA, PATTON CM, TENOVER FC, BARRETT TJ, STAMM WE, STEIGERWALT AG, LIN JY, HOLMES KK, BRENNER DJ 1987: Prevalence and characterization of hippurate-negative Campylobacter jejuni in king county Washington, J Clin Microbiol 25: 1747-1752

VANDAMME P, GOOSSENS H 1992: Taxonomy of Campylobacter, Arcobacter and Helicobacter: A Rewiew. Zbl Bacteriol 276: 447-472

VARGA J, MÉZES B, FODOR L, HAJTOS I 1990: Serogroups of Campylobacter fetus and Campylobacter jejuni isolated in cases of ovine abortion. J Vet Med B 37: 148-152

WAINO M, BANG DD, LUND M, NORDENTOFT S, ANDERSEN JS, PEDERSEN K, MADSEN M 2003: Identification of campylobacteria isolated from Danish broilers by phenotypic tests and species-specific PCR assays. J Appl Microbiol 95: 649-655

WOKATSCH R, BOCKEMUHL J 1988: Serovars and Biovars of Campylobacter strains isolated from humans and slaughterhouse animals in northern Germany. J Appl Microbiol 64: 135-140

WOO PC, LEUNG KW, TSOI HW, WONG SS, TENG JL, YUEN KY 2002: Thermo-tolerant Campylobacter fetus bacteraemia identified by $16 \mathrm{~S}$ ribosomal RNA gene sequencing: an emerging pathogen in immunocompromised patients. J Med Microbiol 51: 740-746

YAZICIOGLU N 2000: The relationship between campylobacter colonization and serum antibody levels in sheep. Etlik Vet Mikrob Derg 11: 31-45 